\title{
JUURNAL.RU
}

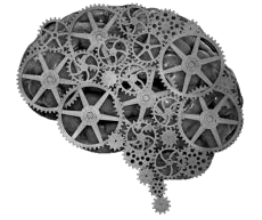

COMPANY GROUP "INTELLEKT"

\author{
Беляева К.Д. \\ ФГБОУ ВПО «Государственный университет управления» \\ Москва, Россия
}

doi: 10.18411//j2016-9-3-02

idsp 000001: lj2016-18-3-02

\section{Пути совершенствования налогового контроля в Российской Федерации: сближение с зарубежным опытом}

\section{Аннотация}

Освещены основные перспективы совершенствования налогового контроля на примере опыта зарубежных стран, а также уделено внимание главным недостаткам налогового контроля, с которыми приходится сталкиваться на практике. Предложено расширение информационного взаимодействия между налоговыми органами и налогоплательщиками, совершенствованием инструментов такого взаимодействия и нормативноправовой базы их функционирования.

Ключевые слова: налоговый контроль, выездные налоговые проверки, текущий контроль, налоговый мониторинг, малый бизнес, проблемы налогообложения.

Повышение эффективности налогового контроля в Российской Федерации и усиление его предупредительной направленности в рамках реформирования всей налоговой системы является одной из важнейших задач государства на современном этапе.

Прозрачность, стабильность, предсказуемость и справедливость налоговой системы является важнейшим конкурентным преимуществом национального бизнес-пространства и, безусловно, влияет на инвестиционную привлекательность.Многие специалисты отмечают оформление такого явления, как налоговая конкуренция между государствами за налоговые ресурсы[7]. 
В создавшихся условиях российские законодатели используют опыт своих зарубежных коллег, что является положительным фактором, так как заимствуется наиболее эффективные инструменты налоговой политики, уже показавшие на практике свою состоятельность. Однако в силу различных экономических систем и различных рынков при заимствовании необходимо сопоставить результирующие итоги внедрений.

Налоговый контроль, как составляющая финансового контроля, представляет собой совокупность действий и операций по проверке финансовых, налоговых и связанных с ними вопросов деятельности субъектов хозяйствования и управления с применением специфических форм и методов его организации и проведения, и обусловленная, главным образом, мобилизацией в государственный бюджет налогов и других обязательных платежей[6].

Существующий государственный, властный характер налогового контроля обусловлен спецификой налоговых правонарушений, основанных на фискальной функции налогов, нежеланием отдельных налогоплательщиков уплачивать налоги. В условиях развивающейся организации налогового контроля, несовершенства налогового законодательства с относительно высоким налоговым бременем властность порождает жалобы на решения налоговых органов. В условиях России, где налоговые законы, зачастую, не прямого действия и допускается их толкование исполнительными органами власти и от лица Министерства финансов России и Федеральной налоговой службы, в отношениях с налогоплательщиками возникают отдельные проблемы.

Ни одна из зарубежных налоговых систем не обходится без такого серьезного и жесткого инструмента налогового контроля, как выездной налоговый контроль. Выездная налоговая проверка представляет вид «ретроспективного», последующего контроля, когда проверяемый период уходит глубоко в прошлое по сравнению с периодом проведения проверки.

В большинстве стран максимальный проверяемый период равен трём годам, однако в некоторых странах, например, в Италии и Франции, он может достигать пяти лет[5].

Несмотря на отсутствие сравнимых по фискальной эффективности альтернатив, нельзя не отметить и ряд серьезных недостатков выездного 
контроля. На наш взгляд, основные недостатки выездного контроля обусловлены тем, что проверяемый период значительно отстоит во времени от периода проверки.

Избежать такого негативного эффекта, добиться согласованности позиций фискальных органов и налогоплательщиков, способствовать установлению доверительных отношений между контролирующими органами и подконтрольными лицами можно путем сокращения роли «ретроспективного», нацеленного на прошедшие налоговые периоды контроля, путем замены его следующими видами контроля и инструментами:

1) Снятие с налогоплательщиков обязанности по исчислению налогов и возложение её на налоговые органы, что исключает необходимость проведения налогового контроля;

2) Увеличение роли текущего контроля, когда отражение хозяйственных операций в учёте налогоплательщика, формирование налоговых обязательств и контроль за этими процессами со стороны налоговых органов происходит одновременно или с минимальной задержкой во времени;

3) Увеличение роли предварительного контроля, введение института согласительных процедур между налоговыми органами и субъектами бизнеса, предваряющих заключение сделки или выбор схемы ведения деятельности, что позволит согласовать позиции участников налоговых правоотношений до наступления потенциально спорной ситуации.

Если первый подход знаком российскому налогоплательщику на примере исчисления имущественных налогов физических лиц, то два следующих подхода в России только предстоит внедрять. Остановимся подробнее на каждом из перечисленных нами подходов, их особенностях и перспективах применения в условиях отечественной налоговой системы.

Снятие с налогоплательщиков обязанности по исчислению налогов и возложение её на налоговые органы реализовано, в частности, при администрировании имущественных налогов физических лиц. Причем с 05.12.2010 действует приказ ФНС России от 05.10.2010 № MМВ-7-11/479@, согласно которому физические лица получают единые уведомления на уплату налога на имущество, земельного и транспортного налогов[3]. 
Очевидно, что рассматриваемый подход будет успешно реализован в тех случаях, когда данные, необходимые для исчисления налога, могут быть получены налоговыми органами без участия налогоплательщика. Следовательно, чем шире перечень данных, получаемых налоговыми инспекциями от иных органов, удобнее и оперативнее способ их получения, тем шире возможности для внедрения рассматриваемого подхода на практике.

Использование названного подхода, безусловно, является для налогоплательщиков, особенно для субъектов малого бизнеса и для физических лиц, максимально удобным, поскольку избавляет от необходимости заполнения деклараций и сбора подтверждающих документов.

Полагаем, что трудовые и временные затраты на расчёт налогов инспекциями значительно ниже затрат на проведение ими же камерального контроля. Полностью будут исключены факты составления решений по результатам камеральных налоговых проверок в тех случаях, когда налог рассчитан правильно, но декларация представлена несвоевременно.

Существует достаточно успешный зарубежный опыт применения рассматриваемого подхода. Так, в Швеции и Финляндии налоговой службой инициировано самостоятельное составление налоговых деклараций за налогоплательщиков, которые затем получают эту декларацию по защищенным каналам связи и могут либо согласиться с ней, либо внести свои изменения и дополнения. В первом случае им достаточно подтвердить эту декларацию, используя механизм электронной подписи, во втором случае им необходимо войти в контакт $\mathrm{c}$ налоговой службой и представить необходимые документальные доказательства в обоснование предлагаемых поправок и изменений[4].

Первые шаги по внедрению текущего налогового контроля и замене им выездного налогового контроля были сделаны российской налоговой системой с введением в Налоговый кодекс РФ раздела V.2. «Налоговый контроль в форме налогового мониторинга» с принятием Федерального закона от 04.11.2014 № 348- Ф3[1].

При этом институт горизонтального мониторинга успешно применяется уже во многих западных странах - Нидерландах, Франции, Германии, США и многих других странах. 
Критерии для организаций, которые имеют право обращаться с заявлением о проведении налогового мониторинга, достаточно жёсткие, и включают ряд показателей деятельности лица за предшествующий налоговому мониторингу год. Так, совокупная сумма НДС, акцизов, налога на прибыль организаций и НДПИ должна составлять не менее 300 миллионов рублей, суммарный объем полученных доходов по данным годовой бухгалтерской (финансовой) отчетности должен составлять не менее 3 миллиардов рублей; совокупная стоимость активов - не менее 3 миллиардов рублей[1].

Полагаем, что введение института налогового мониторинга с перечислеными в п. 3 ст. 105.26 НК РФ критериями станет первым шагом масштабного внедрения текущего налогового контроля, в особенности в интересах представителей малого и среднего бизнеса, которые особо нуждаются в снижении административных барьеров и упрощении процедур налогового администрирования.При этом не исключено, что перечень лиц с особым порядком ведения учёта доходов и расходов в будущем может быть расширен.

В случае, если описанный механизм докажет свою эффективность и получит признание налогоплательщиков, следующим серьезным шагом повышения клиентоориентированности налоговой службы может стать разработка некого унифицированного программного комплекса для ведения учёта доходов и расходов налогоплательщиков определённой категории. Подобный программный комплекс мог бы включать и систему электронного взаимодействия с фискальным ведомством (выгрузка учёта доходов и расходов, сдача отчетности, получение справок и т.д.), и систему взаимодействия с банками (по типу Интернет-банк), и данные о функционировании контрольнокассовой техники.

Такой вид налогового контроля, как предварительный налоговый контроль, при котором мнение налогового органа в отношении сделки или схемы организации бизнеса выражается до заключения этой сделки и внедрения схемы организации бизнеса, и в последующем не подлежит изменению, пока не предусмотрен отечественным законодательством.

Однако часть первая Налогового кодекса РФ содержит следующие нормы, которые косвенно относятся к предварительному налоговому контролю. В соответствии с подп. 2 п. 1 ст. 21 НК РФ налогоплательщики имеют право 
получать от Минфина РФ письменные разъяснения по вопросам применения законодательства о налогах и сборах [1].

Аналогичное правило действует и в случае выполнения мотивированного мнения налогового органа, направленного налогоплательщику в ходе проведения налогового мониторинга. При этом налогоплательщик не освобождается от обязанности уплатить недостающую сумму налогов[1].

Стоит отметить, что в Европе и США институт предварительного налогового регулирования (фискальный рескрипт) является распространенной формой налогового контроля. Его смысл заключается в согласовании налогоплательщиком с налоговым органом налоговых последствий сделок, вопросов ценообразования, распределения прибыли, инвестиционных проектов, иных хозяйственных операций до их фактического совершения.Он реализуется в ходе заключения налоговых соглашений или получения индивидуальных консультаций.

Согласно положениям Свода фискальных процедур Франции, у налогоплательщика есть право направить в фискальный орган запрос о правомерности планируемой операции и получить налоговую консультацию до заключения контракта. Принятое налоговое решение является обязательным как для налоговых органов, так и для налогоплательщика, и изменению не подлежит.

В случае отсутствия ответа в предусмотренные сроки налогоплательщик совершает действия с позиции их полной правомерности, при этом в будущем налоговые органы не вправе рассматривать данную сделку как правонарушение.

Аналогичная процедура предусмотрена законодательством США. Налоговый орган дает письменный ответ налогоплательщику, обратившемуся с предварительным запросом по сделке, которую он намеревается заключить. Полученные ответы применяются в отношении всех аналогичных ситуаций и могут использоваться налогоплательщиками в судах в качестве аргумента.

В Швеции фискальный рескрипт представляет собой выдачу Комиссией по налоговому праву предварительного заключения о налоговых последствиях той или иной сделки. Предварительное заключение является обязательным для налоговых органов и применяется при условии, что налогоплательщик пожелает этого. 
В Германии процедура рескрипта ограничена консультированием налогоплательщиков по вопросам налога на зарплату, таможенных сборов или оценки фактических ситуаций в связи с проведением фискального контроля. Опубликованные позиции, высказанные налоговой администрацией, становятся обязательными для нее, но при этом не налагают ограничений на суд.

Интерес к институту фискального рескрипта появился и у отечественного законодателя. 10.02.2014 распоряжением № 162-р Правительство РФ утвердило план мероприятий («дорожную карту») «Совершенствование налогового администрирования». Пункт 3 Раздела II плана предполагает изучение возможности внедрения института «предварительного налогового разъяснения», сравнительный анализ существующих в мировой практике правовых моделей налоговых разъяснений (соглашений), формирование предложений по правовой модели института предварительного налогового разъяснения для РФ и внесение в Правительство РФ соответствующих предложений.

В результате реализации перечисленных мероприятий государство ожидает формирование оптимальной для России модели института предварительного налогового разъяснения; повышение прозрачности правоприменения законодательства о налогах и сборах; улучшение восприятия инвесторами делового климата; сокращение временных затрат на налоговое администрирование; сокращение количества судебных споров налоговых органов и налогоплательщиков; сокращение времени на проведение контрольных мероприятий[2].

В заключение отметим, что признаком сильного правового государства является либеральная, справедливая и эффективная налоговая система, которая проявляется не столько в больших суммах доначисленных и взысканных налогов, быстроте и качестве разрешения налоговых споров, сколько в сокращении количества ситуаций, когда позиции налогоплательщика и налогового органа противопоставлены друг другу, то есть в уменьшении числа налоговых споров как таковых.В целом, несмотря на имеющийся ряд недостатков, государство находится в постоянном поиске альтернативных способов использования уже существующих форм и методов контроля, в том числе налогового мониторинга и налоговых постов, с целью проверки соответствия законодательству деятельности субъектов хозяйствования с учетом 
соблюдения интересов налогоплательщиков при осуществлении контрольных мероприятий. Расширение практики использования данных форм и методов в перспективе позволит создать новые инструменты налогового контроля, которые будут с одной стороны высокоэффективными, поскольку, заменяя традиционно проводимые проверки субъектов хозяйствования, уменьшат издержки налоговых органов при увеличивающемся охвате сфер деятельности, а с другой стороны - гибкими, отвечающими интересам и налоговых органов, и организаций. 


\section{Литература:}

1. Налоговый кодекс РФ. Часть 1 (в ред. Федерального закона от 29.11.2014 № 382-Ф3). Доступ из справ.-правовой системы «Консультант Плюс».

2. Об утверждении плана мероприятий («дорожной карты») «Совершенствование налогового администрирования» [Электронный ресурс]: распоряжение Правительства РФ от 10.02.2014 № 162-р. Доступ из справ.-правовой системы «Консультант Плюс».

3. Об утверждении формы налогового уведомления [Электронный ресурс]: Приказ ФНС России от 05.10.2010 № ММВ-7-11/479@. Доступ из справ.правовой системы «Консультант Плюс».

4. Малис Н.И. Совершенствование элементов налогового механизма [Текст] // Финансы. - 2015. - № 12. - С. 31-36.

5. Попова Л.В. Налоговые системы зарубежных стран [Текст]: учебнометодическое пособие / Л.В. Попова, И.А. Дрожжина, Б.Г. Маслов. М.: Дело и Сервис, 2014. - 368 с.

6. Сомоев Р.Г. Бюджетный контроль в Российской Федерации Уч. пособие, СПб., Изд-во СПбГУЭФ, 2013.

7. Шувалова Е.Б. Налоговые системы зарубежных стран [Текст]: учебнопрактическое пособие / Е.Б. Шувалова, В.В. Климовицкий, А.М. Пузин. - М.: Изд. центр ЕАОИ, 2010. - 134 с. 